\title{
ENVIRONMENTAL DYNAMISM: THE IMPLICATIONS FOR OPERATIONAL AND DYNAMIC CAPABILITIES EFFECTS
}

\author{
Barbara Petrus \\ Jan Kochanowski University in Kielce, Kielce, Poland \\ e-mail: barbara.petrus@wp.pl \\ ORCID: 0000-0003-3582-2218 \\ (C) 2019 Barbara Petrus \\ This is an open access article distributed under the Creative Commons Attribution-NonCommercial-NoDerivs license \\ (http://creativecommons.org/licenses/by-nc-nd/3.0/)
}

DOI: $10.15611 / \mathrm{ms} .2019 .1 .04$

JEL Classification: M1, L12, M3

\begin{abstract}
The aim of this article is to recognize the implications of various types of environmental dynamism for the effects of operational and dynamical capabilities. The research method used is the critical analysis of literature in the field of strategic management. The research findings in the literature, on the operational effects and dynamic capabilities in the context of environmental dynamism were properly structured in the article. There were controversial research findings on environmental dynamism and its determining of the effects of operational and dynamic capabilities. The results indicate that operational and dynamic capabilities have different performance effects in high-dynamic and low-dynamic environments. The discussion on operational effects and dynamic capabilities in different market conditions still requires better theorizing and empirical research on the implications of market dynamism. The recommendations of the managers are directed at the understanding of the nature of the environment, which is crucial for the success of the implementation of new practices in the company.
\end{abstract}

Keywords: environmental dynamism, dynamic capabilities, operational capabilities, competitive advantage.

\section{Introduction}

Companies perform in the environment that is part of their functioning conditions and generates not only opportunities but threats as well. The general trend in the business environment nowadays is to shorten the product's life and business model cycle [Dyduch 2017, pp. 253-266]. Because of this, future profit streams from existing operations are uncertain, and companies have to seek new opportunities all the time. With the change in the range of products, internal assets and the environment outside, original strategies and key resources may not be strong enough to support companies, which move forward, or they even become obstacles to further development [Leonard-Barton 1992, pp. 111-125]. For this reason, companies should modify, reject or obtain the resources and redesign the business models. The scientific literature brings the examples of different arguments (not) confirming the possibilities of using organizational skills, which may renew their present strategies and the bases of their resources in order to adapt to a new environment, which may be worth mentioning here [Li, Liu 2014, pp. 2793-2799]. This may be considered a premise to learn about the existing theoretical findings and the descriptions of the results of empirical research on the role of environmental dynamism (ED) as a potentially important contextual variable for the effects of operational capabilities (OCs) and dynamic capabilities (DCs). Therefore the aim of this publication is the recognition of the implications of different types of environmental dynamism for operational effects and dynamic capabilities. The realization of this aim will allow to answer the question of how the effects of operational and dynamic capabilities with different levels of environmental dynamism are being shaped. 


\section{The conceptualization of the environmental dynamism}

The environment of a company is the sum of the material and social factors which are taken into account directly during the moment of taking the decision by persons from the company [Li, Liu 2014, pp. 2793-2799]. This broad definition covers the dimensions used in various research trends. The changes taking place in the environment are of a diverse nature. The description of the environment of the company can be shown from the perspective of different groups of features and from a different range of detailed criteria of its structuralisation. The environmental feature is understood as the set of the properties distinguishing or characterizing a feature of the environment being examined.

In the scientific literature there are various interpretations of environmental dynamism, thus it is reasonable to present selected ones. Moreover, thanks to the definitions of environmental dynamism it is possible to learn about the meaning given to this construct for research purposes. In Table 1 some selected definitions of environmental dynamism are presented.

Table 1. The conceptualisation of environmental dynamism

\begin{tabular}{|l|l|}
\hline \multicolumn{1}{|c|}{ Author(s) } & \multicolumn{1}{c|}{ Definition } \\
\hline $\begin{array}{l}\text { Eisenhardt and } \\
\text { Tabrizi (1995) }\end{array}$ & $\begin{array}{l}\text { Environmental dynamism is the pace at } \\
\text { which the competitors, preferences of the } \\
\text { clients and technology change within the } \\
\text { business branch [Eisenhardt, Tabrizi 1995, } \\
\text { pp. 84-110]. }\end{array}$ \\
\hline $\begin{array}{l}\text { Wang and Ang } \\
\text { (2004) }\end{array}$ & $\begin{array}{l}\text { Environmental dynamism is the set of } \\
\text { changes in the competitive environment } \\
\text { which have an impact on the character of } \\
\text { the competitors and the way of reacting to } \\
\text { the demands of the clients and the } \\
\text { development of the branch [Wang, Ang } \\
\text { 2004, pp. 347-363]. }\end{array}$ \\
\hline $\begin{array}{l}\text { Drnevich and } \\
\text { Kriauciunas } \\
\text { (2011) }\end{array}$ & $\begin{array}{l}\text { Environmental dynamism is the change of } \\
\text { the competitive environment, which has an } \\
\text { impact on the way the companies compete } \\
\text { with others and how they respond to the } \\
\text { demands of the clients and the development } \\
\text { of the business branch [Drnevich, } \\
\text { Kriauciunas 2011, pp. 254-279]. }\end{array}$ \\
\hline Li and Liu (2014) & $\begin{array}{l}\text { Environmental dynamism is the volatility } \\
\text { (i.e. the pace of changes and innovations) } \\
\text { as well as the uncertainty or } \\
\text { unpredictability of activities undertaken by } \\
\text { the clients [Li, Liu 2014, pp. 2793-2799]. }\end{array}$ \\
\hline
\end{tabular}

Source: own research based on: [Eisenhardt, Tabrizi 1995, pp. 84-110; Wang, Ang 2004, pp. 347-363; Drnevich, Kriauciunas 2011, pp. 254-279; Li, Liu 2014, pp. 2793-2799].
In defining environmental dynamism (ED), some researchers [Eisenhardt, Tabrizi 1995, pp. 84-110; Wang, Ang 2004, pp. 347-363; Drnevich, Kriauciunas 2011, pp. 254-279; Li, Liu 2014, pp. 2793-2799] rely on the concept of Miller and Friesen [Miller, Friesen 1983, pp. 221-235], who perceive both volatility (the pace and the quantity of the changes), as well as the unpredictability (uncertainty) of the external environment of the company as the main characteristics of environmental dynamism. In other words, ED is defined according to the frequency, quantity and irregularity of competitors' changes, clients' preferences and production technologies or services and the competitive practices in the main branches of industry [Miller, Friesen 1983, pp. 221-235]. Besides, the process of the identification of the environment is of a subjective character.

Dynamic environment is connected with the high unpredictability of clients and competitors as well as the high indicators of the changes of market trends and innovations in the business branch. In such a dynamic environment, where the demand is still changing, the opportunities are getting bigger, and the results should be best in those companies which are oriented on using new changes, because they possess a good match between a strategic orientation and the environment [Azadegan 2013, pp. 193-212].

ED is also defined as the changes in the competitive environment which have an impact on the competitors' character and the way to react to the demands of clients and the situation in the business branch [Wang, Ang 2004, pp. 193-212]. Therefore ED reflects the size and unpredictability of the changes in clients' tastes, production technologies or services and the models of competition in the main companies in the industry [Drnevich, Kriauciunas 2011, pp. 254-279]. Dynamism is interpreted as unpredictability, which means the pace of changes and innovations in the industry, as well as the uncertainty or unpredictability of the actions taken by the customers. Therefore, Wang and others [Wang, Senaratne, Rafiq 2015, pp. 2793-2799] measure ED with the changes in technology, competition and clients, and the construct of market dynamics includes three components: the speed of changes and competition, the unpredictability of changes in technology and competition and the uncertainty of clients' behaviour. Thus the changes in the structure of the branch, the instability of the market demand and the possibility of environmental disruptions are important elements of ED.

Two other interpretations are similar to the ones mentioned before. Li, Liu [2014, pp. 2793-2799] interpret ED as volatility (this means the pace of changes and innovations) in the industry, as well as 
the uncertainty or unpredictability of actions taken by the customers. Eisenhardt and Tabrizi [1995, pp. 84-110] define ED as the pace at which the competition, the preferences of the clients and the technology change within the industry.

Most theoreticians and researchers classify the characteristics of the environment through stability/ dynamism, simplicity/complexity and generosity/ hostility as well as integrated/diversified markets [Li, Liu 2014, pp. 2793-2799]. The generosity of the environment refers to the availability of resources and the number of external opportunities that are present in a specific environment and can also be considered as the rate of return or the growth in the industry in which the company competes [Vij, Bedi, in press]. Dynamic environments provide great opportunities for small enterprises. In particular, market growth is emphasized as an important indicator for small enterprises.

Others [Dess, Beard 1984, pp. 84-110] think that ED is a combination of instability and turbulence. This is defined as the size and unpredictability of the change in the tastes of customers, the technology of production or services, and the possibilities to compete in major industries. Companies competing in the same industry have the same entry and output markets, and technological conditions, in this way defining the environment of the companies [Karna et al. 2016, pp. 1154-1173]. ED describes the rate of changes, unpredictability, volatility and instability in the external environment. ED leads to a great uncertainty which causes deficit of the information needed to identify and understand the cause and effect relationship. When the environment is highly dynamic, uncertainty may suppress the organization's ability to respond to the need for change, predicting customer requirements, questioning the existing strategic direction, and searching for new alternatives. However, an insecure environment in which external changes are nonlinear and inconsistent can also be a great source of opportunities for enterprises to strengthen existing capabilities and/or develop new ones that enable companies to overcome their organizational inertia and shortsightedness of knowledge. According to the scientific literature, this requires a conceptually high need for a strong market research, the fast creation of knowledge and implementing this knowledge into product and market decisions so that they are addressed to changes in a dynamic environment. Some theorists suggest that an environment of great uncertainty forces companies to develop better dynamic capabilities (DCs), which promote the creation of a new, specific knowledge situation and improve creative thinking, leading to the highest innovativeness [Kamasak et al. 2016, pp. 229-253]. Table 2 presents the features of particular types of dynamism of the environment.

Table 2. Types of environmental dynamism and their characteristics

\begin{tabular}{|l|l|l|}
\hline \multicolumn{3}{|c|}{ Types of environmental dynamism } \\
\hline \multicolumn{1}{|c|}{ Low } & \multicolumn{1}{|c|}{ Medium } & \multicolumn{1}{c|}{ High } \\
\hline $\begin{array}{l}\text { Environments } \\
\text { of low } \\
\text { dynamism are } \\
\text { characterized by } \\
\text { rare changes } \\
\text { and the market } \\
\text { participants } \\
\text { anticipate the } \\
\text { changes that } \\
\text { take place. }\end{array}$ & $\begin{array}{l}\text { In the medium } \\
\text { range there are } \\
\text { moderate dynamic } \\
\text { environments with } \\
\text { regular changes } \\
\text { that take place } \\
\text { with predictable } \\
\text { and linear tracks. }\end{array}$ & $\begin{array}{l}\text { On the other hand, } \\
\text { highly dynamic } \\
\text { environments are the } \\
\text { ones where fast and } \\
\text { inconsistent changes are } \\
\text { common. } \\
\text { The companies operating } \\
\text { in a highly dynamic } \\
\text { environment experience } \\
\text { significant fluctuations } \\
\text { in the competition, } \\
\text { changes in the } \\
\text { competitive behaviour } \\
\text { and changes in the } \\
\text { demands of clients and } \\
\text { updating of technology } \\
\text { expressed by high rates } \\
\text { of changes in market } \\
\text { trends and innovations. }\end{array}$ \\
\hline
\end{tabular}

Source: own research based on: [Wilhelm, Schlömer, Maurer 2015, pp. 327-345; Schilke 2014, pp. 179-203; Li, Liu 2014, pp. 2793-2799].

Increased dynamism in the company's environment may cause changes of suppliers, purchasers, the general competitive environment and the nature of competition, which can be a challenge for the company. Competitive pressure, domestic and international changes in supply and demand and government policy force corporations to get involved in adaptive behaviors for their long-term survival. Companies that are becoming increasingly confronted with a more complex and dynamic environment may not have difficulty in adapting and reacting in these environments, unlike the unprepared ones [Azadegan 2013, pp. 193-212]. Therefore companies operating in a highly dynamic environment experience significant fluctuations in competition, changes in competitive behaviour, changes in customer demand and technology updates [Wilhelm, Schlömer, Maurer 2015, pp. 327-345].

The specificity of the environment refers to the availability of the resources and the number of external opportunities that are present in a specific environment [Vij, Bedi 2012, pp. 17-31]. Therefore to improve the results, companies have to use the opportunities in the competitive environment, adjusting their operational capabilities (OCs) to changes in customer trends and 
absorbing new technological trends in due course. It is worth mentioning that companies competing in the same industry face similar entry and output markets, as well as technological conditions defining the environment in which organizations perform [Karna, Richter 2016, pp. 1154-1173].

\section{The effects of operational and dynamic capabilities and various types of environmental dynamism}

Another important issue to be presented is the understanding of operational and dynamic capabilities, and then recognizing their effects in different types of environment. One of the solutions to this problem is referring to the arguments in the form of existing research findings in the scientific literature, which reveal the role of the dynamism of the environment in profiling the effects of these organizational skills. Causal capabilities (operational) include performing the administrative, operational and management functions that are (technically) required to perform tasks. On the other hand, dynamic capabilities include activities on a higher level, which may enable the company to direct ordinary activities towards highly profitable enterprises [Teece 2014, pp. 328-352]. More information on the differentiating characteristics of dynamic and operational capabilities is presented in Wójcik-Karpacz's publication Dynamic capabilities versus operational capabilities [Wójcik-Karpacz 2017b, pp. 51-70].
Bearing in mind their external nature, market conditions have an impact on DCs [Eisenhardt, Martin 2000, pp. 1105-1121; Zahra et al. 2006, pp. 917-955]. The specific characteristics of dynamic capabilities depend on the nature of the environment they operate in, and therefore can be used to enrich the existing configuration of resources (lever logic), or to create a new configuration (chance logic). The condition of the surroundings has a major impact on the character and selection of the dynamic abilities. The more complex and dynamic the environment is, the more the dynamic capabilities will be closer to the unstable processes of low predictability. The reason for this is the short-term analytical perspective, in this situation capabilities are also possible that may have the character of a very simple specific rule or a very openly formulated principle. In moderately dynamic or stable markets, i.e. in conditions where change occurs in the stable structure of the sector, dynamic capabilities resemble the traditional concept of routines as detailed, analytical and permanent processes of predictable results and simultaneously embedded in cumulative existing knowledge [Niemczyk 2017, pp. 303-311].

The results of scientific literature studies in the field of the consequence of environmental dynamism for operational effect and dynamic capabilities are presented in Table 3.

The research findings indicate that even in a highly insecure environment, dynamic capabilities may not effectively improve the results, while in a relatively stable environment the dynamic capabilities are also

Table 3. The implications of various types of environmental dynamism on operational effects and dynamic capabilities

\begin{tabular}{|c|c|c|}
\hline \multirow{2}{*}{$\begin{array}{c}\text { The types } \\
\text { of environmental } \\
\text { dynamism }\end{array}$} & \multicolumn{2}{|c|}{ The types of capabilities considering the hierarchy of abilities } \\
\hline & The effects of dynamic capabilities & The effects of operational capabilities \\
\hline 1 & 2 & 3 \\
\hline Low & $\begin{array}{l}\text { When the environment is relatively stable without a significant } \\
\text { technological progress or a small change in customer preferences, strong } \\
\text { dynamic capabilities are probably expensive or even destructive because } \\
\text { of the maintenance costs, and therefore the relation between dynamic } \\
\text { abilities and competitive advantage may become weaker, and even } \\
\text { negative [Schreyögg, Kliesch-Eberl 2007, pp. 913-933]. } \\
\text { - In an environment characterized by low dynamism, it may be expected } \\
\text { that dynamic capabilities will have a relatively smaller significance for } \\
\text { the company's competitive advantage. These surroundings usually } \\
\text { reward the consistent exploitation of existing resources [Teece 2007, } \\
\text { pp. } 1319-1350 \text { ]. } \\
\text { - A small need to develop dynamic capabilities, only some of the typical } \\
\text { operational business tasks [Li, Liu 2014, pp. 2793-2799]. } \\
\text { - In a relatively stable environment; dynamic capabilities are also useful } \\
\text { to some extent [Li, Liu 2014, pp. 2793-2799]. } \\
\text { - The relation between dynamic capabilities and competitive advantage is } \\
\text { relatively weaker when dynamism is low [Schilke 2014, pp. 179-203]. }\end{array}$ & $\begin{array}{l}\text { - In a relatively stable and predictable } \\
\text { environment, the companies have to } \\
\text { develop basic competences [Wang, } \\
\text { Ahmed 2007, pp. 31-51]. } \\
\text { - Organizations facing a lower level of } \\
\text { environmental dynamism do not have } \\
\text { to adjust their operational capabilities } \\
\text { so often [Wilhelm 2015, pp. 327-345]. }\end{array}$ \\
\hline
\end{tabular}


Table 3, cont.

\begin{tabular}{|c|c|c|}
\hline 1 & 2 & 3 \\
\hline Moderate & $\begin{array}{l}\text { The relation between dynamic capabilities and competitive advantage is } \\
\text { the strongest in intermediate levels of dynamism [Schilke 2014, } \\
\text { pp. 179-203]. } \\
\text { - When the dynamism of the environment is on an intermediate level, } \\
\text { there is both the potential for organizational changes and the ability to } \\
\text { make good use of routine practices that are the basis of dynamic } \\
\text { capabilities [Schilke 2014, pp. 179-203]. }\end{array}$ & $\begin{array}{l}\text { - The changes in the environment } \\
\text { strengthen the relationship between } \\
\text { operational capabilities and results, at } \\
\text { least in the short term [Karna et al. } \\
\text { 2016, pp. 1154-1173]. }\end{array}$ \\
\hline High & $\begin{array}{l}\text { - External changes of the environment force companies to cultivate } \\
\text { dynamic abilities [Li, Liu 2014, pp.2793-2799]. } \\
\text { - The results show that even in highly uncertain environments, dynamic } \\
\text { capabilities may not significantly improve the results [Li, Liu 2014, } \\
\text { pp. 2793-2799]. } \\
\text { - In conditions of a hyper-competitive environment, resources are difficult } \\
\text { to acquire, and as a result efficiently sensing, making adjustments on } \\
\text { time and implementing dynamic capabilities with changing the } \\
\text { environment is the only way for companies to obtain a series of short- } \\
\text { term advantages [D'Aveni et al. 2010, pp. 1371-1385]. } \\
\text { - DCs connected with a high degree of causal ambiguity may lead to } \\
\text { higher results on high-speed markets [Wang, Senaratne, Rafiq 2015, } \\
\text { pp. 26-44]. } \\
\text { - The relation between dynamic capabilities and competitive advantage is } \\
\text { relatively weaker when the dynamism is high [Schilke 2014, pp. 179-203]. } \\
\text { If the dynamism of the environment is high and the contextual changes } \\
\text { are fundamental and inconsistent, long-term reorientations that require } \\
\text { completely innovative solutions, often turn out to be more beneficial to } \\
\text { the competitive advantage of the company than local adaptations from } \\
\text { the set of activities available at the moment [Schilke 2014, pp. 179-203]. }\end{array}$ & $\begin{array}{l}\text { - In highly changing environment, } \\
\text { companies need to change and improve } \\
\text { their core competencies to develop } \\
\text { a higher level of dynamic capabilities } \\
\text { [Wang, Ahmed 2007, pp. 31-51]. } \\
\text { - A high-dynamics environment offers } \\
\text { even more opportunities and options to } \\
\text { improve existing operational capabili- } \\
\text { ties [Wilhelm et al. 2015, pp. 327-345]. } \\
\text { - Operational capacity can also help } \\
\text { businesses to take full advantage of } \\
\text { new opportunities, e.g. by allowing } \\
\text { them to rapidly increase production to } \\
\text { meet increased demand. We generally } \\
\text { believe that the dynamism of the } \\
\text { environment increases the effects of } \\
\text { operational capabilities on the } \\
\text { company's results. (Karna et al. 2016, } \\
\text { pp. 1154-1173]. }\end{array}$ \\
\hline
\end{tabular}

Source: [Schreyögg, Kliesch-Eberl 2007, pp. 913-933; Teece 2007, pp. 1319-1350; Wang, Ahmed 2007, pp. 31-51; D’Aveni, Dagnino, Smith 2010, pp. 1371-1385; Schilke 2014, pp. 179-203; Wilhelm, Schlömer, Maurer 2015, pp. 327-345; Wang, Senaratne, Rafiq 2015, pp. 26-44; Karna, Richter, Riesenkampff 2016, pp. 1154-1173].

useful to some extent. This finding shows also that regardless of the condition of the environment, the dynamic capabilities are an important and stable source of competitive advantage. The main reason may be the fact that when the environment is getting more and more unstable, the companies may be more sensitive and develop a higher level of dynamic capabilities, however the impact of dynamic capabilities on competitive advantage does not necessarily have to be stronger [Li, Liu 2014, pp. 2793-2799].

When the environment is relatively stable without significant technological progress or a small change in customer preferences, strong dynamic capabilities are probably expensive or even destructive because of the maintenance costs [Schreyögg, Kliesch-Eberl 2007, pp. 913-933], and therefore the relation between dynamic abilities and competitive advantage may become weaker, and even negative [Li, Liu 2014, pp. 2793-2799]. In an environment characterized by low dynamism, it may be expected that dynamic capabilities will have a relatively smaller significance for the company's competitive advantage. These surroundings usually reward the consistent exploitation of existing resources [Teece 2007, pp. 1319-1350], while a continuous reconfiguration of resources may disrupt the effectiveness and value of the company's resources. Therefore the positive impact of dynamic capabilities on the competitive advantage of the company will be comparatively low when the dynamism of the environment is low [Schilke 2014, pp. 179-203]. When the dynamism of the environment is low, the potential of dynamic abilities is limited. In such situations, organizational routines of adaptation of the resource base may have a reduced value, especially taking into account the related costs [Schilke 2014, pp. 179-203]. Thus when the dynamism of the environment is low, dynamic capabilities have a relatively weak influence on the competitive advantage.

However, when the dynamism of the environment is on an intermediate level, there is both the potential for organizational changes and the ability to make good use of routine practices that are the basis of dynamic capabilities. In conclusion, one expects that the positive effect of dynamic abilities will first increase, but will then decrease, as environmental dynamism still increases, and finally decreases with a high level of dynamics. This is tested empirically below [Schilke 2014, pp. 179-203]. 
On the other hand, in highly volatile environments, opportunities quickly disappear, and threats from the competitors are always nearby, such environmental turbulences reduce the competitive position and potential value of current capabilities, forcing companies to make frequent and complex changes, so dynamic capabilities can have a more important role [Li, Liu 2014, pp. 2793-2799]. Scientists confirm that when the dynamism of the environment is high, dynamic capabilities may also have a relatively small impact on the competitive advantage. Although the highly dynamic environment provides ample opportunities for the reconfiguration of resources, the high frequency of new situations and the need to introduce inconsistent organizational change make routine mechanisms based on relatively less appropriate ones, because of matching and inertia related problems. Dynamic abilities will have the relatively strongest positive impact on competitive advantage when the dynamism of the environment is indirect. These environments are dynamic enough to create opportunities for change, but also stable enough that organizations can recognize the repetitive structures of problems and effectively use the solutions existing in the organizational memory [Schilke 2014, pp. 179-203].

D'Aveni and the others [2010] believe that in a hyper-competitive environment, resources are difficult to achieve, and as a result effective sensing, making adjustments at the appropriate moment and dynamic implementation with changing the environment is the only way for companies to obtain a set of short-term advantages. On the contrary, in a less-fierce environment where resources are easy to acquire, companies can implement strategies from the past and freely position resources to adapt to changes in the environment so that relatively weak dynamic capabilities can gain long-term competitive advantages [Li, Liu 2014, pp. 2793-2799].

Moreover, dynamic capabilities directly struggle with changes in the environment that imply the driving role of the dynamism of the environment. In a relatively stable and predictable environment, companies have to develop basic competences [Wang, Ahmed 2007, pp. 31-51], while in highly changing environments, companies have to change and improve their core competencies to develop a higher level of dynamic capabilities [Li, Liu 2014, pp. 2793-2799].

Continuing the discussion, in an environment with relatively large and rich resources. low competition and a high increase in total sales in the industry, companies face less competition and they appreciate the opportunities more, and with little demand to develop dynamic capabilities, only some of the typical operational business tasks [Li, Liu 2014, pp. 2793-2799]. While in a hyper-competitive environment, companies have to maintain close observation of various uncertainties, such as technological innovation, the threats of new entrants and the risk of unaccomplished tasks by contractors, and should look for more information to arrange resources, perform more complicated and sophisticated analyses, taking more timely decisions and implement them to develop dynamic capabilities [Li, Liu 2014, pp. 2793-2799].

A highly dynamic environment and the demand for new activities are an evident challenge for the effectiveness of dynamic capabilities. Adapting unknown situations to organizational changes may be difficult and lead to a lack of reaction or normalization and to implement inappropriate responses.

In essence, the typical reaction of companies to the growing dynamism of the environment is the development of dynamic capabilities. In a highly dynamic environment, companies need to improve the perception of change, for example, if customer requirements have changed, companies should make the necessary adjustments to fit them. It can be said that external changes of the environment force companies to cultivate dynamic abilities. [Li, Liu 2014, pp. 2793-2799] DCs connected with a high degree of causal ambiguity may lead to better results in high velocity markets than in markets with moderate dynamics [Wang, Serenate, Rafiq 2015, pp. 26-44].

When markets are dynamic (i.e. rapidly changing and unpredictable), companies need to develop the ability to adjust their resource base quickly to maintain a high level of performance. If a company possesses resources/competences but lacks dynamic capabilities, it has the opportunity to make a competitive return for a short period, but superior returns cannot be sustained [Ivens et al., in press].

Moreover, Schilke claims that the impact of DCs on the results of the company is dependent on the market dynamism. It is suggested to use nonlinear, moderated inverted U-shaped models, suggesting that the relationship between dynamic capabilities and competitive advantage is the strongest in intermediate levels of dynamism, but relatively weaker when the dynamism is low or high [Schilke 2014, pp. 179-203].

Some researchers suggest that the dynamism of the company's environment can increase the efficiency of dynamic capabilities and their potential for competitive advantage. Others, however, suggest that, on the contrary, dynamic abilities may prove less effective in a highly dynamic environment [Schilke 2014, pp. 179-203].

At present, there are two competing views on the impact of the environment dynamism on the 
links between dynamic capabilities and competitive advantage, with little integration of both perspectives. The first view suggests that there is a critical need to change in order to get a significant value from these abilities [Schilke 2014, pp. 179-203].

This happens because creating and using dynamic capabilities is expensive. These costs are usually caused by various activities related to evolving new resources, the reconfiguration of the existing ones and their combinations. Additional costs may arise if the continuous reconfiguration of resources unnecessarily disturbs the continuity of learning activities, preventing the company from recognizing the potential differences in the results of its resources under different conditions [Schilke 2014, pp. 179-203. Other significant costs may result from the wrong estimation of the demand to change resources, which happens when companies use their dynamic capabilities when there is no significant need to change [Winter 2003, pp. 991-995]. This may lead to significant costs, as frequent disruptions to the basic resource base can harm structural reproducibility and therefore reduce the organization's ability to perform as a credible and responsible cooperative unit [Schilke 2014, pp. 179-203]. Naturally, the assumption that the development of dynamic capabilities [Wójcik-Karpacz 2017a, pp. 341-366] requires serious costs has an impact on their potential value. If a company rarely has the need for change, its performance against its competitors may suffer as it allocates significant resources to develop these capabilities. This observation underlines the importance of balancing the costs of a given dynamic ability and its actual usage [Schilke 2014, pp. 179-203].

It can be said that environmental dynamism has an impact both on the opportunites to change and the organizational ability to exploit these opportunities via routine-based change.

Companies in a low dynamic environment seem to benefit less from developing and maintaining dynamic capabilities than organizations operating in a highly dynamic environment. In a stable environment, boundary conditions change more slowly, and the goals are in place for comparatively longer time-frames. Therefore the need to adjust the operational capabilities of the organization is lower than in the dynamic environment. At the same time, an environment with high dynamics offers even more opportunities and options to improve the existing operational capabilities. However, this may also be true for companies performing in a lowdynamic environment, where the results of adjusting operational capabilities will be probably incremental and rare [Wilhelm et al. 2015, pp. 327-345].
Operational capabilities (OCs) are the principle of sine qua non for company success. Changing environmental conditions do not decrease, but rather increase the attention of the companies that do what they do the best they can. Therefore the value of the capability does not depend only on the need for the company to control changes in the environment, and they are also needed in a stable environment [Karna et al. 2016, pp. 1154-1173].

Companies do not necessarily create dynamic capabilities only from external pressures, but still need internal pulling forces and subjective efforts. In other words, dynamic capabilities are the result of the co-evolution of internal and external forces [Li, Liu 2014, pp. 2793-2799]. The changing industry environment requires that companies have to adapt their existing organizational capabilities and update their resource base, and dynamic capabilities allow that [Karna et al. 2016, pp. 1154-1173].

\section{Conclusions}

The effects of operational and dynamic capabilities depend on the environmental dynamism experienced by individual companies. Environmental dynamism can be defined in terms of the frequency, size and irregularity of changes in competition, customer preferences and technology. In that case, the key issue of the management team is the acceptance of uncertainty.

What is important is that the scientific literature findings question the role of the environment dynamism as a necessary precondition of dynamic operational capabilities, and instead opt for a distinguishing approach on how the operational and dynamic effects are formed under different levels of environmental dynamism. In general, dynamic capabilities increase general results, but they are not likely for every company in every kind of the environment.

The scientific literature review shows a more diverse view of environmental dynamism. A high level of environmental dynamism continuously creates new opportunities for companies. However, when operating at a lower level of environmental dynamics there is less chance of improving operational capabilities, and quick reactions are not so critical.

\section{Bibliography}

Augier M., Teece D.J., 2009, Dynamic capabilities and the role of managers in business strategy and economic performance, Organization Science, 20(2), pp. 410-421.

Azadegan A., Patel P.C., Zangoueinezhad A., Linderman K., 2013, The effect of environmental complexity and environ- 
mental dynamism on lean practices, Journal of Operations Management, 31(2013), pp. 193-212.

D’Aveni R.A., Dagnino G.B., Smith K.G., 2010, The age of temporary advantage, Strategic Management Journal, vol. 31, no. 13.

Dess G.G., Beard D.W., 1984, Dimensions of organizational task environments, Administrative Science Quarterly, 29(1), pp. 52-73.

Dess G., Beard D., 1984, Dimensions of organizational task environments, Administrative Science Quarterly, 29(1), pp. 52-73

Drnevich P.L., Kriauciunas A.P., 2011, Clarifying the conditions and limits of the contributions of ordinary and dynamic capabilities to relative firm performance, Strategic Management Journal, 32, pp. 254-279.

Duncan R.B., 1972, Characteristics of organizational environments and perceived environmental uncertainty, Administrative Science Quarterly, vol. 17, no. 3.

Dyduch W., 2017, Strategiczny projekt wspierający rozwój zdolności dynamicznych, [w:] Krzakiewicz K., Cyfert Sz., (ed.), Strategiczny wymiar dynamicznych zdolności polskich przedsiębiorstw, Wydawnictwo UEP, Poznań, pp. 341-366.

Eisenhardt K.M., Tabrizi B.N., 1995, Accelerating adaptive processes: product innovation in the global computer industry, Administrative Science Quarterly, vol. 40, pp. 84-110.

Eisenhardt K.M., Martin J.A.M., 2000, Dynamic capabilities: What are they?, Strategic Management Journal, vol. 21, no. 10/11, pp. 1105-1121.

Englewood NJ Cliffs, see: Da-yuan Li, Juan Liu, 2014, Dynamic capabilities, environmental dynamism, and competitive advantage: Evidence from China, Journal of Business Research, 67 , pp. 2793-2799; no. 28(4), pp. 328-352.

Ivens B.S., Leischnig A., Pardo C., Niersbach B., Key account management as a firm capability, Industrial Marketing Management, in press.

Kamasak R., Yavuz M., Altuntas G., 2016, Is the relationship between innovation performance and knowledge management contingent on environmental dynamism and learning capability?, Evidence from a turbulent market, Business Research, 9, pp. 229-253.

Karna A., Richter A., Riesenkampff E.,2016, Revisiting the role of the environment in the capabilities-financial performance relationship: a meta-analysis, Strategic Management Journal, 37, pp. 1154-1173.

Leonard-Barton D., 1992, Capabilities and core rigidities: a paradox in managing new product development, Strategic Management Journal, vol. 13, Special Issue: Strategy Process: Managing Corporate Self-Renewal (Summer, 1992), pp. 111-125.

Li D., Liu J., 2014, Dynamic capabilities, environmental dynamism, and competitive advantage: evidence from China, Journal of Business Research, 67, pp. 2793-2799.

Miller D., Friesen PH., 1983, Strategy-making and environment: the third link, Strategic Management Journal, 4(3), pp. 221-235.
Mintzberg H., 1983, Structure in fives: designing efficient organizations, Prentice-Hall.

Niemczyk J., 2017, Analiza strategii organizacji z perspektywy wybranych podejść do strategii, [in:] Krzakiewicz K., Cyfert Sz. (ed.), Strategiczny wymiar dynamicznych zdolności polskich przedsiębiorstw, Wydawnictwo UEP, pp. 303-311.

Obłój K., 2007, O zarządzaniu refleksje, Wydawnictwo MT Biznes, pp. 95-97.

Schilke O., 2014, On the contingent value of dynamic capabilities for competitive advantage: the nonlinear moderating effect of environmental dynamism, Strategic Management Journal, 35, pp. 179-203.

Schreyögg G., Kliesch-Eberl M., 2007, How dynamic can organizational capabilities be? Towards a dual-process model of capability dynamization, Strategic Management Journal, 28(9), pp. 913-933.

Teece D.J., 2007, Explicating dynamic capabilities: the nature and microfoundations of (sustainable) enterprise performance, Strategic Management Journal, 28(13), pp. 1319-1350.

Teece D.J., 2014, The foundations of enterprise performance: $d y$ namic and ordinary capabilities in an (economic) theory of firms, The Academy of Management Perspectives, no. 28(4), pp. 328-352.

Vij S., Bedi S.H., 2012, Relationship between entrepreneurial orientation and business performance, A Review of Literature, Journal of Business Strategy, vol. IX, no. 3.

Wang C.K., Ang B.L., 2004, Determinants of venture performance in Singapore, Journal of Small Business Management, vol. 42, no. 4, pp. 347-363.

Wang C.L., Ahmed P.K., 2007, Dynamic capabilities: A review and research agenda, International Journal of Management Reviews, vol. 9, no. 1.

Wang C.L., Senaratne Ch., Rafiq M., 2015, Success traps, dynamic capabilities and firm performance, British Journal of Management, vol. 26, pp. 26-44.

Wiklund J., 1999, The sustainability of the entrepreneurial orientation-performance relationship. Entrepreneurship: Theory \& Practice, 10422587, Fall, vol. 24, no. 1.

Wilhelm H., 2015, Schlömer M., Maurer I., How dynamic capabilities affect the effectiveness and efficiency of operating routines under high and low levels of environmental dynamism, British Journal of Management, vol. 26.

Winter S.G., 2003, Understanding dynamic capabilities, Strategic Management Journal, 24(10), pp. 991-995.

Wójcik-Karpacz A., 2017a, Mechanizmy i ścieżki rozwoju zdolności dynamicznych, [w:] Krzakiewicz K., Cyfert Sz. (ed.), Strategiczny wymiar dynamicznych zdolności polskich przedsiębiorstw, Wydawnictwo UEP, Poznań, pp. 341-366.

Wójcik-Karpacz A., 2017b, Zdolności dynamiczne versus zdolności operacyjne, Organizacja i Kierowanie, no. 1, pp. 51-70.

Zahra S.A., Sapienza H.J., Davidsson P., 2006, Entrepreneurship and dynamic capabilities: a review, model and research agenda, Journal of Management Studies, 43(4), pp. 917-955. 


\section{DYNAMIZM OTOCZENIA: IMPLIKACJE DLA EFEKTÓW OPERACYJNYCH I DYNAMICZNYCH ZDOLNOŚCI}

Streszczenie: Celem artykułu jest rozpoznanie wpływu różnych rodzajów dynamizmu otoczenia na efekty zdolności operacyjnych i dynamicznych. Zastosowana metoda badawcza to krytyczna analiza literatury z zakresu zarządzania strategicznego. Wyniki badań literaturowych, dotyczące efektów operacyjnych i możliwości dynamicznych w kontekście dynamizmu środowiskowego, zostały w artykule odpowiednio ustrukturyzowane. Wskazano niejednoznaczność wyników badań nad dynamiką środowiska i określeniem jego skutków dla zdolności operacyjnych i dynamicznych. Dowiedziono, że zdolności operacyjne i zdolności dynamiczne wywołują różne efekty w otoczniach o wysokiej i niskiej dynamice. Dyskusja na temat efektów operacyjnych i dynamicznych zdolności w różnych warunkach rynkowych wymaga dalszych badań teoretycznych i empirycznych dotyczących wpływu dynamiki rynku. Zalecenia menedżerskie są ukierunkowane na zrozumienie natury środowiska, co jest kluczowe dla powodzenia wdrażania nowych praktyk w firmie.

Słowa kluczowe: dynamizm otoczenia, zdolności dynamiczne, zdolności operacyjne, przewaga konkurencyjna. 